\title{
PENGARUH PARKIR PADA BADAN JALAN TERHADAP KAPASITAS JALAN
}

\author{
Dian Hastari Agustina ${ }^{1}$ \\ 1) Dosen Tetap Prodi Teknik Sipil Universitas Riau Kepulauan
}

\begin{abstract}
ABSTRAK
Tingkat pelayanan jalan sangat dipengaruhi oleh kapasitas dan arus lalu lintas yang ada. Penambahan sarana fisik jalan secara terus menerus jelas sulit dilaksanakan karena besarnya dana yang dibutuhkan dan juga keterbatasan lahan yang ada, sedangkan pertumbuhan lalu lintas dari tahun ke tahun cenderung menunjukkan peningkatan. Jika jumlah kepemilikan kendaraan sekitar 0,1 mobil per rumah tangga yang mungkin masih akan mengalami peningkatan yang berarti pula akan terjadi kenaikan arus lalu lintas di masa mendatang. Tulisan ini difokuskan pada pengaruh parkir pada badan jalan terhadap kapasitas jalan untuk menentukan tingkat pelayanan yang terjadi, dilaksanakan pula pengamatan volume kendaraan yang parkir pada badan jalan dan pengaruh sudut parkir kendaraan yang berkaitan dengan pengurangan lebar perkerasan jalan. Diharapkan dapat memberikan masukan dan solusi terhadap masalah yang berkaitan dengan pengaturan lalu lintas dan parkir pada untuk menghindari gangguan lalu lintas dan kembali memfungsikan jalan sesuai statusnya sebagai jalan Arteri Primer.
\end{abstract}

\subsection{Latar Belakang}

Permasalahan lalu lintas di perkotaan saat ini tidak hanya kemacetan tetapi termasuk di dalamnya masalah parkir karena keterbatasan lahan dan perencanaan tata kota yang kurang baik. Masalah ini tidak hanya terbatas di kota-kota besar seperti Jakarta, Surabaya tetapi juga di kotakota berukuran sedang termasuk Batam. Semakin meningkatnya tingkat perekonomian masyarakat ini dibarengi pula meningkatnya kepemilikan kendaraan, munculnya pusat-pusat perbelanjaan baru di kota-kota dan berkembangnya gaya hidup konsumtif pada masyarakat kota saat ini.

Pemusatan lokasi-lokasi perbelanjaan juga terjadi dengan suatu pertimbangan akan memudahkan masyarakat dalam memenuhi kebutuhannya, akibatnya terjadi pula pemusatan kegiatan transportasi pada lokasi-lokasi tertentu. 
Dari data yang ada walaupun jalan-jalan baru sudah dibangun serta ruas-ruas jalan yang ada telah diperlebar tetapi ini masih tidak dapat mengimbangi kenaikan arus lalu lintas dan pertambahan jumlah kendaraan setiap tahunnya. Membangun atau memperlebar jalan secara terus-menerus sulit untuk dilaksanakan karena keterbatasan biaya sehingga sudah saatnya mempertimbangkan untuk membebaskan badan jalan dari beban sebagai tempat parkir kendaraan di beberapa lingkungan komersial.

\subsection{Kapasitas Jalan}

Adalah jumlah kendaraan maksimum yang dapat melewati suatu tampang jalan pada jalur jalan selama satu jam dengan kondisi serta arus lalu lintas tertentu.

Ada tiga golongan kapasitas, yaitu :

1. Kapasitas Dasar (Kapasitas Ideal), adalah jumlah kendaraan maksimum yang dapat melintasi suatu tampang pada suatu jalur/jalan selama satu jam, dalam keadaan jalan dan lalu lintas yang mendekati ideal (gangguan tidak ada) yang dapat dicapai.

2. Kapasitas Mungkin, adalah jumlah kendaraan maksimum yang dapat melewati suatu tampang pada suatu jalur/jalan selama satu jam, dalam keadaan lalu lintas yang sedang berlaku pada jalan tersebut (tanpa memperhatikan pengaruh memperlambat kendaraan dan yang membatasi kendaraan untuk berjalan bebas).

3. Kapasitas Praktis (Kapasitas Sesungguhnya), adalah jumlah kendaraan maksimum yang dapat melintasi satu tampang pada suatu jalur/jalan selama satu jam dalam keadaan jalan dan lalu lintas yang sedang berlaku sedemikian sehingga kepadatan lalu lintas yang bersangkutan mengakibatkan kelambatan, bahaya dan gangguan-gangguan pada kelancaran lalu lintas yang masih dalam batas yang ditetapkan.

\subsection{Tingkat Pelayanan}

Dalam hal ini digunakan untuk mengukur kualitas perjalanan.

Untuk menetapkan tingkat pelayanan digunakan dua faktor utama, yaitu : 
1. Kecepatan perjalanan (kecepatan tempuh), adalah kecepatan rata-rata $(\mathrm{km} / \mathrm{jam})$ arus lalu lintas dihitung dari panjang ruas jalan dibagi waktu tempuh rata-rata kendaraan lewat ruas jalan tersebut.

Pada saat volume meningkat, kebebasan pengemudi dalam memilih kecepatan kendaraannya menjadi terbatas yang menyebabkan turunnya kecepatan.

2. Derajat Kejenuhan (degree of saturation), didefinisikan sebagai ratio arus terhadap kapasitas sebagai faktor utama dalam penentuan tingkat kinerja suatu segmen jalan. Nilai DS menujukkan apakah segmen jalan tersebut mempunyai masalah kapasitas atau tidak, jika nilai DS > 0,8 perlu dilakukan perbaikan. DS dihitung dengan menggunakan arus dan kapasitas dinyatakan dalam smp/jam.

\subsection{Parkir}

Keberadaan fasilitas parkir mutlak diperlukan karena sarana untuk pengangkutan orang maupun barang tidak selalu dalam keadaan bergerak terus, tetapi memerlukan berhenti di tempat-tempat tertentu yang mungkin bersifat sementara dalam waktu relatif pendek atau berhenti dalam waktu yang cukup lama.

Berdasarkan tata letaknya terhadap badan jalan, jenis parkir dibagi menjadi dua macam, parkir pada badan jalan dan parkir di luar badan jalan.

1. Parkir pada badan jalan

Jenis parkir ini sebaiknya dihindari. Idealnya kendaraan di parkir di tempat yang telah disediakan di luar badan jalan. Namun demikian kadang-kadang kendaraan terpaksa di parkir pada badan jalan karena fasilitas parkir di luar badan jalan tidak mencukupi (seperti di pasar, pertokoan, perkantoran) atau memang tidak tersedianya fasilitas parkir di luar badan jalan (Siti Malkhamah, 1994).

Pengaruh dari kendaraan yang parkir di atas lebar efektif jalan seringkali jauh lebih besar daripada banyaknya ruang yang dipergunakan. Seorang pengemudi yang merasa khawatir akan terjadinya gerakan kendaraan lain atau terbukanya pintu secara mendadak dapat menyebabkan hilangnya lebar jalan sebesar 12 sampai $14 \mathrm{ft}$ (Clarkson H. Oglesby dan R. Gary Hicks, 1993). 
Berkurangnya kapasitas jalan dipercepat dan dipengaruhi oleh tiga faktor berikut ini :

a. cara parkir (tegak lurus, miring, atau sejajar dengan arus),

b. volume lalu lintas pada jalan bersangakutan,

c. besarnya kebutuhan tempat parkir pada jalan tersebut yang menghambat kelancaran arus lalu lintas kendaraan karena kendaraan-kendaraan yang sedang mencari tempat parkir.

Disamping itu masih ada hal lain yang ikut mempengaruhi yaitu jumlah mobil yang terparkir sepanjang jalan. Sekalipun hanya beberapa kendaraan yang diparkir sepanjang ruas jalan, kendaraan-kendaraan itu secara efektif mengurangi lebar jalan dan hal itu berarti mengurangi kemampuan tampung lalu lintas, dapat dikatakan kapasitasnya dikurangi. Hanya tiga buah kendaraan mobil yang diparkir pada ruas jalan sepanjang $1 \mathrm{~km}$, akan secara efektif mengurangi lebar jalan 5,5 m menjadi 4,6 m yaitu dari jalan yang dibangun untuk standar lalu lintas dua arah turun menjadi satu arah (G.R. Wells, 1994). The Ministry of Transport menyusun tabel parkir sebagai berikut .

\section{Tabel 1. Hubungan Volume Parkir terhadap Pengurangan Lebar dan Kapasitas Jalan}

\begin{tabular}{|l|cccccc|}
\hline $\begin{array}{l}\text { Parkir kendaraan per km } \\
\text { (dua sisi jalan ) }\end{array}$ & 3 & 6 & 30 & 60 & 120 & 300 \\
\hline Pengurangan lebar (m) & 0,9 & 1,2 & 2,1 & 2,5 & 3,0 & 3,7 \\
\hline $\begin{array}{l}\text { Pengurangan kapasitas } \\
\text { pada 24 km/jam } \\
\text { (smp/jam ) }\end{array}$ & 200 & 275 & 475 & 575 & 675 & 800 \\
\hline
\end{tabular}

sumber : Urban Traffic Engineering Technique, Tabel 7.

Disadari penggunaan sisi jalan sebagai ruang parkir adalah murah akan tetapi masalahmasalah keselamatan akan selalu timbul, 50\% kecelakaan yang terjadi di ruas jalan di daerah perkotaan, diakibatkan berkurangnya kebebasan pandangan, adanya kendaraan berhenti, masuk atau keluar secara mendadak dari tempat parkir yang mengganggu arus kendaraankendaraan yang menerus. 
Penggunaan badan jalan untuk fasilitas parkir kendaraan, sebenarnya hanya dapat dilakukan pada jalan kolektor atau lokal dengan memperhatikan :

a. kondisi jalan dan lingkungan,

b. kondisi lalu lintas dan aspek keselamatan,

c. ketertiban dan keselamatan lalu lintas.

Agar daerah-daerah pusat kegiatan dapat tetap hidup dengan baik, masalah parkir perlu ditangani dengan penataan kembali aspek parkir dan pendayagunaan pemanfaatan ruas jalan dengan prioritas pada kelancaran arus.

2. Parkir di luar badan jalan

Peniadaan ataupun pembatasan peruntukkan parkir pada suatu ruas jalan akan memberikan konskewensi terhadap penyediaan fasilitas di luar jalan yang jelas membutuhkan biaya lebih mahal, meskipun demikian pusat kegiatan yang memiliki tempat parkir yang baik, aman dan nyaman akan lebih menarik minat pengunjung dibanding yang tidak memiliki tempat parkir.

Parkir di luar badan jalan misalnya pada pelataran parkir (parking space) dan gedung parkir (parking bulding). Bangunan parkir dapat dilaksanakan di atas atau di bawah tanah. Beberapa keuntungan off street parking adalah :

a. banyak memberikan ruangan maksimum,

b. memberikan kenyamanan kendaraan yang parkir dan tidak menganggu kelancaran lalu lintas bagi kendaraan yang tidak parkir,

c. mengurangi keruwetan jalan masuk dan keluar dengan gerakan kendaraan serta pejalan kaki di luar bidangnya. 


\subsection{Tingkat pelayanan}

a. Gunakan kondisi masukan yang ditentukan dalam langkah A dan kecepatan arus bebas dan kapasitas yang ditentukan dalam langkah B danb. tentukan derajat kejenuhan, kecepatan dan waktu tempuh.

1) Derajat kejenuhan

Dengan menggunakan kapasitas sesungguhnya, hitung ratio antara $Q$ dan $C$ untuk menentukan derajat kejenuhan DS.

Persamaan yang digunakan sebagai berikut :

$$
\mathrm{DS}=\mathrm{Q} / \mathrm{C}
$$

keterangan :

$\mathrm{Q}=$ Arus/volume lalu lintas (smp/jam)

$\mathrm{C}=$ Kapasitas sesungguhnya ( $\mathrm{smp} / \mathrm{jam})$

Dari nilai DS yang diperoleh dapat menunjukkan apakah segmen jalan tersebut mempunyai masalah kapasitas atau tidak.

\section{Contoh :}

Diketahui :

$\mathrm{Q}=1866 \mathrm{smp} / \mathrm{jam}$

$\mathrm{C}=2709,9072$ smp/jam (hal. 35)

Maka :

$\mathrm{DS}=1866 / 2709,9072$

$$
=0,689
$$

2) Kecepatan dan waktu tempuh 
a) Tentukan kecepatan pada kondisi lalu lintas, hambatan samping dan kondisi geometrik sesungguhnya sebagai berikut dengan menggunakan gambar 4.5 sebagai berikut :

(1) masukkan nilai derajat kejenuhan (DS) pada sumbu horisontal pada bagian bawah gambar,

(2) buat garis sejajar dengan sumbu vertikal (Y) dari titik tersebut sampai berpotongan dengan nilai kecepatan arus bebas sesungguhnya $(\mathrm{FV})$,

(3) buat garis horisontal sejajar dengan sumbu (X) sampai berpotongan dengan sumbu vertikal (Y) pada bagian sebelah kiri gambar dan lihat nilai kecepatan kendaraan ringan sesungguhnya untuk kondisi yang dianalisa,

(4) masukkan nilai ini ke dalam kolom.

b) masukkan panjang segmen $\mathrm{L}(\mathrm{km})$

c) hitung waktu tempuh rata-rata untuk kendaraan ringan dalam jam untuk kondisi yang diamati, dan masukkan hasilnya

Persamaan waktu tempuh rata-rata sebagai berikut :

$$
\mathbf{T T}=\mathbf{L} / \mathbf{V}(\mathbf{j a m})
$$

( waktu tempuh rata-rata dalam detik dapat dihitung dengan TT x 3600).

\section{Contoh :}

Diketahui :

$\mathrm{L}=0,450 \mathrm{~km}$

$\mathrm{V}=40,3 \mathrm{~km} / \mathrm{jam}$ (sesuai hasil perolehan gambar 4.5 dan data $\mathrm{Q} / \mathrm{C}$ dan $\mathrm{FV}$ yang diketahui)

Maka :

$\mathrm{TT}=0,450 / 40,3$

$=0,0112 \mathrm{jam} / 40,32$ detik 
3) Evaluasi tingkat pelayanan

Dari hasil evaluasi akan dapat diketahui apakah kondisi segmen jalan yang diamati masih memenuhi persyaratan tingkat pelayanan $\mathrm{C}$ untuk jalan perkotaan. Apabila kondisi di lapangan tidak sesuai dengan perencanaan dan persyaratan maka diperlukan beberapa perbaikan, terutama kondisi geometrik untuk memperoleh tingkat pelayanan sesuai yang diinginkan berkaitan dengan kapasitas, kecepatan dan sebagainya.

Untuk memperoleh salah satu nilai yang dianggap memenuhi dari semua nilai yang diperoleh selama pengamatan di lapangan, maka dihitung rata-rata/mean (X), standar deviasi (s) dan nilai karakteristik (r) dari semua data yang diperoleh dengan rumus :

$$
\bar{X}=\frac{X_{1}+X_{2}+\ldots+X n}{n}
$$

$$
\begin{aligned}
& s=\sqrt{\frac{\sum(X i-\bar{X})^{2}}{n-1}} \\
& r=X-t_{\alpha, n-1} \cdot(s / \sqrt{ } n)
\end{aligned}
$$

keterangan :

$\mathrm{X}=$ nilai rata-rata $($ mean $)$

$\mathrm{S} \quad=$ standar deviasi sampel

$\mathrm{r} \quad=$ nilai karakteristik

$\mathrm{n} \quad=$ jumlah sampel

$\mathrm{n}-1=$ degrees of freedom

$\alpha \quad=$ tingkat significance

$\mathrm{t}=$ distribusi $\mathrm{t}$ pada derajat kebebasan $\mathrm{n}-1$ 
(sumber : Konsep-konsep Probabilitas dalam Perencanaan dan Perancangan Rekayasa,1992, Alfredo H-S. Ang dan Wilson H. Tang).

\subsection{Prosedur Perhitungan Parkir}

\section{Penawaran parkir}

\section{a. Satuan ruang parkir}

Penentuan satuan ruang parkir (SRP) didasarkan atas hal berikut :

1) Dimensi kendaraan standar untuk mobil penumpang.

Pada tabel 4.13. dapat dilihat karakteristik mobil penumpang menurut beberapa standar.

Tabel 2. Karakteristik mobil penumpang

\begin{tabular}{|c|c|c|c|c|c|c|c|}
\hline Standar & $\begin{array}{c}\text { Panjang } \\
\text { total } \\
(\mathrm{m})\end{array}$ & $\begin{array}{c}\text { Lebar } \\
\text { total } \\
(\mathrm{m})\end{array}$ & $\begin{array}{c}\text { Tinggi } \\
(\mathrm{m})\end{array}$ & $\begin{array}{c}\text { Depan } \\
\text { tergantung } \\
(\mathrm{m})\end{array}$ & $\begin{array}{c}\text { belakang } \\
\text { tergantung } \\
(\mathrm{m})\end{array}$ & $\begin{array}{c}\text { Jarak } \\
\text { gandar } \\
(\mathrm{m})\end{array}$ & $\begin{array}{c}\text { radius } \\
\text { putaran } \\
\text { min. } \\
(\mathrm{m})\end{array}$ \\
\hline AASHTO & 5,8 & 2,14 & 1,3 & 0,9 & 1,5 & 3,35 & 7,3 \\
\hline Jepang & 4,7 & 1,7 & 2,0 & 0,8 & 1,2 & 2,7 & 6,0 \\
\hline NAASRA & 4,74 & 1,86 & - & 0,813 & 1,1 & - & - \\
\hline $\begin{array}{c}\text { Bina } \\
\text { Marga }\end{array}$ & 4,7 & 1,7 & 2,0 & 0,8 & 1,2 & 2,7 & 6,0 \\
\hline
\end{tabular}

sumber : 1. AASHTO, 1984

2. NAASRA, 1988

3. Standar Perencanaan Geometri Jalan Perkotaan,Ditjen Bina Marga, DPU

2) Ruang bebas arah lateral dan memanjang.

- Ruang bebas arah lateral diasumsikan sebesar $5 \mathrm{~cm}$. 
- Ruang bebas arah memanjang diasumsikan $30 \mathrm{~cm}$.

3) Lebar bukaan pintu kendaraan.

Dapat dilihat dalam tabel

Tabel 3. Lebar bukaan pintu

\begin{tabular}{|c|l|l|}
\hline Golongan & \multicolumn{1}{|c|}{ Jenis bukaan pintu } & Penggunaan fasilitas parkir \\
\hline I & $\begin{array}{l}\text { Pintu terbuka tahap awal } \\
55 \mathrm{~cm}\end{array}$ & $\begin{array}{l}\text { - Karyawan kantor } \\
\text { - Tamu pusat perkantoran, } \\
\text { pemerintahan, mahasiswa }\end{array}$ \\
\hline II & Pintu terbuka penuh & $\begin{array}{l}\text { - Pengunjung perdagangan, } \\
\text { pusat belanja, fasilitas olah } \\
\text { raga, } \\
\text { rumah sakit }\end{array}$ \\
\hline III & $\begin{array}{l}\text { Pintu terbuka penuh } \\
\text { ditambah pergerakan kursi } \\
\text { roda }\end{array}$ & Orang cacat \\
\hline
\end{tabular}

sumber : Pedoman teknis Penyelenggaraan Fasilitas Parkir,Departemen Perhubungan, Ditjen. Perhubungan Darat.

Dari uraian di atas maka satuan ruang parkir (SRP) berubah seperti yang tertera dalam tabel 4.

Tabel 4. Penentuan satuan ruang parkir (SRP)

\begin{tabular}{|l|c|}
\hline \multicolumn{1}{|c|}{ Jenis kendaraan } & Satuan Ruang Parkir $(\mathrm{m})$ \\
\hline 1. - mobil penumpang golongan I & $2,30 \times 5,00$ \\
- mobil penumpang golongan II & $2,50 \times 5,00$ \\
- mobil penumpang golongan III & $3,00 \times 5,00$ \\
\hline 2. sepeda motor & $0,75 \times 2,00$ \\
\hline
\end{tabular}

a) Satuan ruang parkir untuk mobil penumpang

Keterangan : 


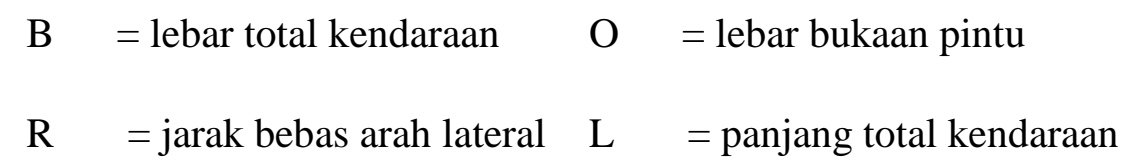

a1,a2 = jarak bebas longitudinal

(1) Golongan I
$B=170$
$\mathrm{a} 1=10$
$\mathrm{Bp}=230$
$\mathrm{L}=470$
$\mathrm{O}=55$
$\mathrm{a} 2=20$
$\mathrm{Lp}=500$
$\mathrm{R}=50$

(2) Golongan II
$B=170$
$\mathrm{a} 1=10$
$\mathrm{Bp}=250$
$\mathrm{L}=470$
$\mathrm{O}=75$
$\mathrm{a} 2=20$
$\mathrm{Lp}=500$
$\mathrm{R}=60$

(3) Golongan III
$B=170$
$\mathrm{a} 1=10$
$\mathrm{Bp}=300$
$\mathrm{L}=470$
$\mathrm{O}=75$
$\mathrm{a} 2=20$
$\mathrm{Lp}=500$
$R=65$

\section{b. Pola parkir}

1) Pola parkir paralel

2) Pola parkir menyudut

a) Lebar ruang parkir, ruang parkir efektif dan ruang manuver berlaku untuk jalan kolektor dan lokal.

b) Lebar ruang parkir, ruang parkir efektif dan ruang manuver berbeda berdasarkan besar sudut berikut ini :

(1) sudut $30^{\circ}$ 
Tabel 5. Pola parkir dengan sudut $30^{\circ}$

\begin{tabular}{|l|c|c|c|c|c|}
\hline & $\mathrm{A}$ & $\mathrm{B}$ & $\mathrm{C}$ & $\mathrm{D}$ & $\mathrm{E}$ \\
\hline Golongan I & 2,3 & 4,6 & 3,45 & 4,70 & 7,6 \\
Golongan II & 2,5 & 5,0 & 4,30 & 4,85 & 7,75 \\
Golongan III & 3,0 & 6,0 & 5,35 & 5,0 & 7,9 \\
\hline
\end{tabular}

(2) sudut $45^{\circ}$

Tabel 6. Pola parkir dengan sudut $45^{\circ}$

\begin{tabular}{|l|c|c|c|c|c|}
\hline & $\mathrm{A}$ & $\mathrm{B}$ & $\mathrm{C}$ & $\mathrm{D}$ & $\mathrm{E}$ \\
\hline Golongan I & 2,3 & 3,5 & 2,5 & 5,6 & 9,3 \\
Golongan II & 2,5 & 3,7 & 2,6 & 5,65 & 9,35 \\
Golongan III & 3,0 & 4,5 & 3,2 & 5,75 & 9,45 \\
\hline
\end{tabular}

(3) sudut $60^{\circ}$

Tabel 7. Pola parkir dengan sudut $60^{\circ}$

\begin{tabular}{|l|c|c|c|c|c|}
\hline & $\mathrm{A}$ & $\mathrm{B}$ & $\mathrm{C}$ & $\mathrm{D}$ & $\mathrm{E}$ \\
\hline Golongan I & 2,3 & 2,9 & 1,45 & 5,95 & 10,55 \\
Golongan II & 2,5 & 3,0 & 1,5 & 5,95 & 10,55 \\
Golongan III & 3,0 & 3,7 & 1,85 & 6,0 & 10,6 \\
\hline
\end{tabular}

(4) sudut $90^{\circ}$

Tabel 8. Pola parkir dengan sudut $90^{\circ}$

\begin{tabular}{|l|c|c|c|c|c|}
\hline & $\mathrm{A}$ & $\mathrm{B}$ & $\mathrm{C}$ & $\mathrm{D}$ & $\mathrm{E}$ \\
\hline Golongan I & 2,3 & 2,3 & - & 5,4 & 11,2 \\
Golongan II & 2,5 & 2,5 & - & 5,4 & 11,2 \\
Golongan III & 3,0 & 3,0 & - & 5,4 & 11,2 \\
\hline
\end{tabular}




\section{Keterangan table 4-8 :}
$\mathrm{A}=$ Lebar ruang parkir $(\mathrm{m})$
$\mathrm{C}=$ Selisih panjang ruang parkir $(\mathrm{m})$
$\mathrm{B}=$ Lebar kaki ruang parkir $(\mathrm{m})$
$\mathrm{D}$ = Ruang parkir efektif $(\mathrm{m})$
$\mathrm{E}=$ Ruang parkir efektif ditambah ruang manuver $(\mathrm{m})$
$\mathrm{M}=$ Ruang manuver $(\mathrm{m})$

\section{c. Daya tampung dan luas ruang parkir}

Daya tampung ruang parkir sangat dipengaruhi oleh pola parkir kendaraan yaitu posisi saat parkir, sejajar atau membentuk sudut tertentu terhadap as jalan. Besar daya tampung ruang parkir suatu ruas jalan ditetapkan sebagai berikut :

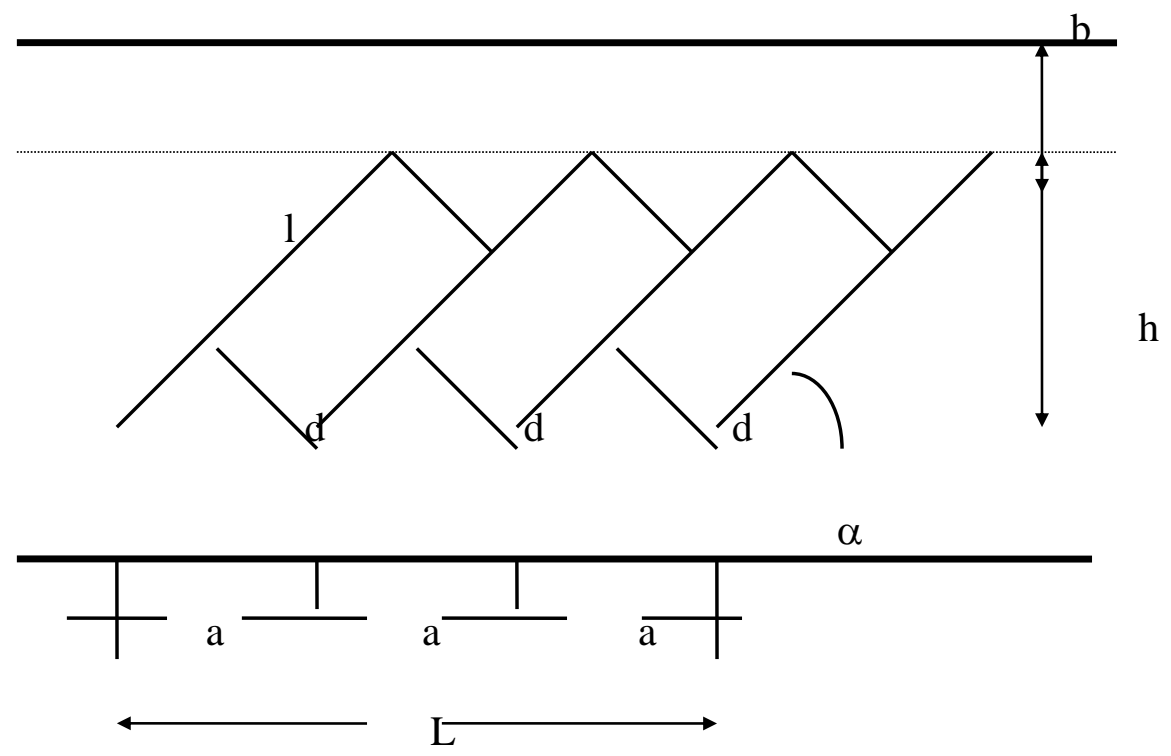

Gambar 4.14. Sketsa ruang parkir

\section{Keterangan :}

$\mathrm{a}=\mathrm{d} / \sin \alpha$ 


$$
\begin{array}{ll}
\mathrm{b} & =1 \cos \alpha-\mathrm{a} \cos ^{2} \alpha \\
\mathrm{h} & =(1-\mathrm{a} \cos \alpha) \cdot \sin \alpha
\end{array}
$$

Tabel 9. Daya tampung mobil penumpang golongan I

\begin{tabular}{|c|c|c|c|c|}
\hline & $30^{\circ}$ & $45^{\circ}$ & $60^{\circ}$ & $90^{\circ}$ \\
\hline $\mathrm{a}$ & 4,6 & 3,2527 & 2,6558 & 2,3 \\
\hline $\mathrm{b}$ & 0,8801 & 1,9092 & 1,8360 & - \\
\hline $\begin{array}{c}\text { Daya } \\
\text { tampun } \\
\mathrm{g}\end{array}$ & $\underline{\mathrm{L}-0,8801}$ & $\underline{\mathrm{L}-1,9092}$ & $\underline{\mathrm{L}-1,8360}$ & $\underline{\mathrm{L}}$ \\
\hline $\mathrm{h}$ & 4,6 & 3,2527 & 2,6558 & 2,3 \\
\hline $\mathrm{B}$ & $3,0-3,5$ & $3,0-3,5$ & 5,1 & $6,0-8,0$ \\
\hline
\end{tabular}

Tabel 10. Daya tampung mobil penumpang golongan II

\begin{tabular}{|c|c|c|c|c|}
\hline & $30^{\circ}$ & $45^{\circ}$ & $60^{\circ}$ & $90^{\circ}$ \\
\hline $\mathrm{a}$ & 5,0 & 3,5355 & 2,8867 & 2,5 \\
\hline $\mathrm{b}$ & 0,5801 & 1,7678 & 1,7783 & - \\
\hline $\begin{array}{c}\text { Daya } \\
\text { tampun } \\
\mathrm{g}\end{array}$ & $\frac{\mathrm{L}-0,5801}{\mathrm{~h}}$ & $\underline{\mathrm{L}-1,7678}$ & $\underline{\mathrm{L}-1,7783}$ & $\underline{\mathrm{L}}$ \\
\hline $\mathrm{h}$ & 4,665 & $5,3,3033$ & 6,4434 & 2,5 \\
\hline B & $3,0-3,5$ & $3,0-3,5$ & 4,6 & $6,0-8,0$ \\
\hline
\end{tabular}

Sedangkan luas areal parkir dihitung dengan cara sebagai berikut :
$\mathrm{A}=\mathrm{L}(\mathrm{B}+\mathrm{H})$
$\mathrm{N}=(\mathrm{L}-\mathrm{b}) / \mathrm{a}$
$\mathrm{L}-\mathrm{b}=\mathrm{a} \cdot \mathrm{N}$ 


$$
A=(\mathbf{a} \cdot \mathbf{N}+\mathbf{b})(\mathbf{B}+\mathbf{h})
$$

keterangan :

$$
\mathrm{A}=\operatorname{Luas}\left(\mathrm{m}^{2}\right)
$$

$\mathrm{N}=$ Daya tampung

\section{Contoh Kasus}

\section{Segmen I (mulai persimpangan J1.Prof.DR.H.Yohanes Yogyakarta)}

Kondisi yang ada :

- Daerah perkotaan

- Kelas hambatan samping tinggi, karena terdapat pertokoan pada kanan-kiri jalan (komersial), banyaknya pejalan kaki, parkir pada dua sisi jalan, kendaraan umum berhenti dengan frekwensi tinggi, banyak kendaraaan lambat (becak, gerobak dorong pedagang kaki lima), dan adanya pedagang kaki lima yang berjualan di trotoar.

- Lebar jalan 15,7 m

- Lebar lajur rata-rata 3,75 m

- Jumlah lajur 4

- Dengan parkir dua sisi (sisi utara untuk kendaraan roda empat dan sisi selatan untuk kendaraan roda dua)

- Jumlah lajur efektif 2

- Ukuran kota sedang

- Jarak rata-rata kereb ke penghalang 1,5 m 
Hitungan dilakukan sebagai berikut :

\section{Arus Lalu Lintas}

Untuk menghitung arus lalu lintas, digunakan dasar bahwa hari Senin - Kamis, Sabtu -

Minggu, LHR (lalu Lintas Harian Rata-rata) hampir sama, sedangkan Jumat LHR akan berbeda. Sehingga perhitungan dilakukan sebagai berikut.

\# Data arus lalu lintas (periode 07.00 - 08.00)

- Data arus lalu lintas pada hari Senin

$$
=1866 \mathrm{smp} / \mathrm{jam}
$$

- Data arus lalu lintas pada hari Jumat

$$
=1824 \mathrm{smp} / \mathrm{jam}
$$

- Data arus lalu lintas pada hari Sabtu

$$
=1918 \mathrm{smp} / \mathrm{jam}
$$

Maka nilai arus lalu lintas dalam seminggu :

$$
(4 \times 1866)+(1 \times 1824)+(2 \times 1918)=13124 \text { smp/jam }
$$

$$
\begin{aligned}
* \text { Mean }(\mathbf{X}) & =13124 / 7 \\
& =1874.86 \mathrm{smp} / \mathrm{jam}
\end{aligned}
$$

\section{* Standar deviasi (s)}

$$
\begin{aligned}
& =\sqrt{\frac{4 *(1866-1874.86)^{2}+(1824-1874.86)^{2}+2 *(1918-1874.86)}{(7-1)}} \\
& =33.22
\end{aligned}
$$

$*$ Nilai karakteristik $=1874.86-1.943 *(33.22 / \sqrt{ } 7)$ 


$$
=1850.46
$$

\section{Derajat kejenuhan}

Dihitung dengan cara yang sama seperti perhitungan arus lalu lintas.

\section{Kecepatan}

Untuk menghitung kecepatan diambil nilai rata-rata kecepatan berdasar data berikut

\section{\# Kecepatan arus}

\begin{tabular}{|c|c|c|c|}
\hline \multicolumn{3}{|l|}{ Segmen I } \\
\hline Interval & $x$ & $f$ & $f . x$ \\
\hline $33-33.9$ & 1 & 33.45 & 33.45 \\
$34-34.9$ & 3 & 34.45 & 103.35 \\
$35-35.9$ & 12 & 35.45 & 425.35 \\
$36-36.9$ & 8 & 36.45 & 291.60 \\
$37-37.9$ & 6 & 37.45 & 224.70 \\
$38-38.9$ & 6 & 38.45 & 230.70 \\
$39-39.9$ & 6 & 39.45 & 236.70 \\
& 42 & & 1545.90 \\
\hline
\end{tabular}

$\operatorname{Rata-rata}(\mathbf{X})=\Sigma(\mathbf{f . x} / \mathbf{f})$ 
* X segmen $I=\frac{}{42}=36.8071 \mathrm{~km} / \mathrm{jam}$

\section{Waktu tempuh}

Dihitung berdasarkan hasil rata-rata kecepatan yang terjadi.

* Segmen I $\quad: \quad$ - panjang segmen jalan $=0.450 \mathrm{~km}$

$$
\begin{array}{ll}
- \text { kecepatan rata-rata } & =36.8071 \mathrm{~km} / \mathrm{jam} \\
\text { Waktu tempuh } & =0.450 / 36.8071 \\
& =0.0122 \mathrm{jam}
\end{array}
$$

Dari hasil analisis segmen I kondisi parkir pada sisi jalan, sangat mempengaruhi tingkat pelayanan dan kecepatan arus. Dapat dilihat perbandingan arus (Q) dan derajat kejenuhan (DS), sedangkan kecepatan arus (Vlv) dapat dilihat perhitungannya pada table berikut.

Tabel 10. Perbandingan kondisi arus (Q) dan derajat kejenuhan (DS)

\begin{tabular}{|c|c|c|}
\hline Periode & Arus (Q) & $\begin{array}{c}\text { Derajat } \\
\text { kejenuhan } \\
\text { (DS) }\end{array}$ \\
\cline { 2 - 3 } & segmen I & segmen I \\
\hline $07.00-08.00$ & 1850.46 & 0.680 \\
$08.00-09.00$ & 1901.81 & 0.702 \\
\hline
\end{tabular}




\begin{tabular}{|l|l|l|}
\hline $09.00-10.00$ & 2108.63 & 0.777 \\
$10.00-11.00$ & 2217.48 & 0.818 \\
$11.00-12.00$ & 2228.56 & 0.823 \\
$12.00-13.00$ & 2275.79 & 0.840 \\
$13.00-14.00$ & 2271.57 & 0.839 \\
$14.00-15.00$ & 2080.06 & 0.768 \\
$15.00-16.00$ & 2071.47 & 0.764 \\
$16.00-17.00$ & 1971.85 & 0.728 \\
$17.00-18.00$ & 2167.90 & 0.800 \\
$18.00-19.00$ & 2212.15 & 0.816 \\
$19.00-20.00$ & 2242.11 & 0.827 \\
$20.00-21.00$ & 2109.40 & 0.779 \\
\hline
\end{tabular}

\section{Kesimpulan}

Tidak tersedianya areal parkir yang memadai di pusat perkantoran maupun pertokoan menyebabkan konsumen memarkir kendaraannya pada badan jalan, yang berakibat terganggunya arus lalu lintas.

Gangguan-gangguan lalu lintas yang cenderung ke arah kemacetan umumnya disebabkan karena kendaraan yang berhenti di sembarang tempat karena tidak adanya bus stop, kurang sadarnya para penyeberang jalan untuk menyeberang pada zebra cross, pedagang-pedagang kaki lima yang memenuhi trotoar yang mengganggu arus pejalan kaki sehingga pejalan kaki banyak yang berjalan pada badan jalan, adanya kelambatan arus karena arus menerus yang harus ikut memperlambat kendaraannya untuk memberi kesempatan bagi kendaraan yang akan masuk/keluar areal parkir dan juga karena penggunaan ruang manuver bagi kendaraan parkir yang cukup besar.

\section{Daftar Pustaka}


Anonim, 1996, Manual Kapasitas Jalan Indonesia, Direktorat Pembinaan Jalan Perkotaan, Direktorat Jenderal Bina Marga, Jakarta.

Anonim, 1988, Standar Perencanaan Geometrik untuk Jalan Perkotaan, Departemen Pekerjaan Umum, Direktorat Jenderal Bina Marga, Jakarta.

Anonim, 1996, Pedoman Teknis Penyelenggaraan Fasilitas Parkir, No.272/HK.105/JRD/96, Departemen Perhubungan, Direktorat Jenderal Perhubungan Darat, Jakarta.

Anonim, 1965, Highway Capacity Manual, Highway Research Board, Special Report 87, Washington D.C. USA.

Ang, A.H.S., dan Tang, W.H., 1992, Konsep-konsep Probabilitas dalam Perencanaan dan Perancangan Rekayasa, Penerbit Erlangga Jakarta.

Ashley, C., 1994, Traffic and Highway Engineering for Developments, Blackweel Scientific Publications, Oxford, England.

Diktat Kuliah, 1996, Teknik Lalu Lintas, mata kuliah Teknik Lalu Lintas.

Hobbs, F.D., 1995, Perencanaan dan Teknik Lalu Lintas, Gajah Mada University Press, Yogyakarta.

Malkhamah, S., 1994, Survei, Lampu Lalu Lintas dan Pengantar Manajemen Lalu Lintas, Biro Penerbit KMTS FT UGM.

Matson, T.M., Smith, W.S., Hurd, F.W.,1955, Traffic Engineering, Mc.Graw-Hill Book Company, USA.

Oglesby, C.H., dan Hicks, R.G., 1993, Teknik Jalan Raya, Penerbit Erlangga, Jakarta.

Sukirman, S., 1992, Dasar-dasar Geometrik Jalan, Penerbit Nova, Bandung.

Wells, G.R., 1993, Rekayasa Lalu Lintas, Penerbit Bhratara, Jakarta. 